\title{
Relative carriage rates of nuclear dehydrogenating clostridia in two populations of different colorectal cancer risk
}

\author{
SP BORRIELLO, BS DRASAR,* A TOMKINS,* MJ HILL
}

From the Bacterial Metabolism Research Laboratories, PHLS Centre for Applied Microbiology and Research, Porton Down, Salisbury, Wiltshire, and the *London School of Hygiene and Tropical Medicine, London WCI

SUMMARY Carriage of nuclear dehydrogenating clostridia has been associated with colon cancer and implicated in its aetiology. This study has compared the carriage of these organisms in a British population at high risk for the development of colon cancer with a low risk Nigerian population. Clostridia were found in all of the stools from both populations. Nuclear dehydrogenating clostridia were only found in the stools of the British subjects $(32 \%)$. These results support the suggestion that the carriage rate of nuclear dehydrogenating clostridia in a population is related to the risk of colon cancer.

Cancer of the large bowel is primarily a disease of western countries' and has been strongly associated with diet. The epidemiology of the disease has been reviewed recently by Correa and Haenszel. ${ }^{2}$ Current theories on its aetiology have suggested that it is caused by carcinogens or tumour promoters produced in the colon by bacterial metabolism ${ }^{34}$ and particular interest has centred on the possible role of bile acids as substrates. ${ }^{5}$ One of the possible classes of metabolites of interest is the unsaturated bile acids. A large screening study of more than 1000 strains of intestinal bacteria by Goddard et at showed that certain types of clostridia were the only intestinal bacteria able to dehydrogenate the steroid nucleus at the $\triangle^{4}$ position to yield an unsaturated product. An association between carriage of these nuclear dehydrogenating clostridia (NDC) and large bowel cancer was demonstrated by Hill $e t a l^{7}$ in a case control study and this has been confirmed by Borriello (unpublished observations, 1977) and Blackwood et al. ${ }^{8}$ Populations with a low incidence of large bowel cancer rarely carry the species that most commonly produce unsaturated bile acids. ${ }^{69}$ However, the strains of clostridia examined in this and a later study in Hong Kong ${ }^{10}$ had been isolated some time before the testing of their dehydrogenating activity. Thus, loss of activity or selection of inactive strains may have occurred during storage.

As part of a study of infant malnutrition in Nigeria there was an opportunity to collect and study faecal samples from infant and adult Nigerians. Large bowel cancer is rare in Nigeria ${ }^{11112}$ and so the opportunity was taken to assay these samples for NDC.

Accepted for publication 21 July 1982

\section{Material and methods}

STOOL SAMPLES

Stools were collected from 53 British adults of longstanding residence in the UK and from 17 adults from Gamzago, a hamlet in Malumfashi district, a rural savannah area 70 miles north of Zaria, Nigeria. None of the subjects included in the study had any history of previous gastrointestinal malignancy or of any gastrointestinal disease known to be associated with colorectal cancer. The stool samples from the UK subjects were either stored frozen at $-20^{\circ} \mathrm{C},{ }^{13}$ or a small amount of stool (approximately $0.5 \mathrm{~g}$ ) was placed in a preweighed 5 $\mathrm{ml}$ screw-capped bottle containing $4.5 \mathrm{ml}$ of glycerol transport broth (GTB). The added stool was emulsified with the aid of a Vortex mixer and then frozen and stored at $-20^{\circ} \mathrm{C} .{ }^{13} \mathrm{~A}$ small weighed sample of the stool specimens from Nigerian subjects was diluted tenfold in $10 \%$ GTB within $45 \mathrm{~min}$ of collection and frozen in liquid nitrogen stored in a portable field refrigerator. All samples were processed within 1 month of receipt. The Nigerian samples were collected during the months of April and May (dry season). Those from the United Kingdom were collected over the period January to June of the previous year.

MICROBIOLOGICAL ANALYSIS

All manipulations were performed in an anaerobic cabinet. Serial tenfold dilutions of the stool samples were made in Brain Heart Infusion broth. The prepared samples were heated to $75^{\circ} \mathrm{C}$ for $20 \mathrm{~min}$ on a dry block heater to select for clostridial spores. Aliquots $(0.1 \mathrm{ml})$ of these dilutions were seeded onto an egg-yolk base 
Table I Comparison of faec al clostridia of Nigerian and UK subjects

\begin{tabular}{|c|c|c|c|c|c|}
\hline \multirow[t]{2}{*}{ Subject(No) } & \multicolumn{5}{|c|}{ Mean $\log _{11} N o / g($ Range $)$ Median $\log _{11} N o / g$} \\
\hline & Total clostridia & \multicolumn{2}{|l|}{ Lecithinase +ie } & Lecithinase - we & $N D C$ \\
\hline $\begin{array}{l}\text { Nigerian( } 17) \\
\text { UK (53) }\end{array}$ & $\begin{array}{l}6 \cdot()(3 \cdot 0-7 \cdot 8) 6 \cdot 2 \\
5 \cdot 3(3 \cdot 0-7 \cdot 8) 5 \cdot 3\end{array}$ & $5 \cdot 9(3 \cdot 0-7 \cdot 8) 6 \cdot 2$ & & $\begin{array}{l}1 \cdot 1(\mathrm{ND}-5 \cdot 1)() \\
5 \cdot 1(3 \cdot()-7 \cdot 8) 5 \cdot 1\end{array}$ & $\begin{array}{l}\text { ND } \\
1.7(\mathrm{ND}-7 \cdot 4) 0\end{array}$ \\
\hline \multicolumn{6}{|c|}{$\begin{array}{l}\text { NDC = Clostridia capable of dehydrogenating the steroid nucleus at the } \triangle^{4} \text { position. } \\
\text { ND }=\text { Not detected. }\end{array}$} \\
\hline \multirow{6}{*}{\multicolumn{3}{|c|}{$\begin{array}{l}\text { medium. The seeded plates were incubated in an } \\
\text { anacrobic environment at } 37^{\circ} \mathrm{C} \text { for } 3 \text { days. All of the } \\
\text { techniques and conditions used have been described } \\
\text { previously. After incubation total counts were estimated } \\
\text { and } 10 \text { colonies from each stool sample were transferred to } \\
\text { Robertson's eooked meat medium (RCM) for further } \\
\text { analysis. Colonies were chosen from plates consisting of } \\
30 \text { to } 100 \text { colonies. The choice of colonies was random. }\end{array}$}} & \multicolumn{3}{|c|}{$\begin{array}{l}\text { Table } 2 \text { Carriage of clostridia capable of dehydrogenating the } \\
\text { steroid mucleas (ND)H clostridia) }\end{array}$} \\
\hline & & & & Britishadulss & Vigerian adults \\
\hline & & & \multirow{4}{*}{$\begin{array}{l}\text { Koof subjects } \\
\text { "c carriage of NDC } \\
\text { Large bousel cancer rish } \\
\text { Colon } \\
\text { Rectum }\end{array}$} & 53 & 17 \\
\hline & & & & 32 & 0 \\
\hline & & & & $\begin{array}{l}\text { High } \\
24 \cdot 7\end{array}$ & $\begin{array}{l}\text { Low } \\
(0 \cdot 4: 4\end{array}$ \\
\hline & & & & $15 \cdot 5$ & 0.4 \\
\hline
\end{tabular}

3-()X()-5/3STEROII) $\Delta^{+}$DIEHYDRO(IENASE ACTINTY The clostridia isolated from faeces were tested for their ability to dehydrogenate the steroid nucleus at the $\triangle^{+}$ position. Three drops of Todd-Hewitt broth (Oxoid) containing $0.005 \% \mathrm{wt} / \mathrm{vol}$ of $5 / 3$-androstan-3-17-dione were added to each well of a microtitre tray (Sterilin Ltd). A Pasteur pipette was used to deliver two drops of a three-day culture in RCM to each well. Each well was inoculated with a different isolate. An uninoculated well served as a negative control and a nuclear dehydrogenating strain of Clostridium paraputrificum as a positive control. The inoculated trays were incubated anaerobically. At $48 \mathrm{~h}$ one drop of 5/3-androstan-3-17-dione menadione stock solution was added (5/3-androstan-3-17dione. $(0 \cdot 5 \mathrm{~g}$. menadione. $(0.35 \mathrm{~g}$, ethyl alcohol $100 \mathrm{ml}$ : filter sterilise). The trays were reincubated anaerobically for a maximum of $18 \mathrm{~h}$ and a minimum of $12 \mathrm{~h}$. After incubation $10 \mu \mathrm{l}$ of the contents of each of 10 wells were simultaneously spotted onto a TLC plate (Polygram Silica $\mathrm{Gel} / \mathrm{UV} 254$ thin layer chromatography plates of $0.25 \mathrm{~mm}$ thickness Camlab-Cambridge) by use of a set of 10 fixed phage loops which have been previously described. ${ }^{15}$ The plates were run in benzene-dioxan-water 100:10:1 (vol vol). All plates included a 4-androsten-3-17-dione standard. The plates were air dried and observed under ultraviolet light $(\lambda=254 \mathrm{~nm})$ for the production of 4-androsten-3-17-dione. The plates could then be sprayed with anisaldehyde reagent and the colour allowed to develop in a hot oven at $80^{\circ} \mathrm{C}$.

\section{Results}

Both populations harboured clostridia in all of the stool samples analysed. The Nigerian samples yielded slightly higher counts of total clostridia with a mean of $10^{6 \cdot 0} / \mathrm{g}$ stool compared to $10^{5 \cdot 3} / \mathrm{g}$ stool for UK residents (Table 1). The Nigerian clostridial flora was composed predominantly of lecithinase positive clostridia ( all of which were ( perfingens). whereas the UK clostridial flora was predominantly lecithinase-negative in nature (Table 1 )음 Clostridia with the ability to dehydrogenate the steroict nucleus at the $\triangle^{+}$position (NDC) were not detected in the्ष stools of Nigerians but they were recovered from $32 \%$ o the stools of UK residents at a mean concentration of $10^{1.7} \mathrm{~g}$ stool (Table 2). The mean number of NDC in the subjects that carried these organisms was $10^{5 \cdot 1} / g$ stool $\underset{\infty}{\infty}$

\section{Discussion}

Data on the carriage of NDC by various populations aro sparse. The study of Drasar et $a l^{9}$ concentrated upon the identity of the clostridia isolated from the faeces o populations living in England. Wales. Scotland. USA $\overrightarrow{\vec{B}}$ Japan. Hong Kong. and Uganda. The most striking finding was the low carriage rate of $C$ paraputrificum in areas of low cancer incidence and the comparatively high rate in areas of high incidence; however the clostridit examined had been in culture for between five and eighp years and there are no data on changes in dehydrogenating activity during such prolonged storage. Goddard et $a l^{6}$ in a parallel study examined the faccal clostridia isolatec from these subjects. showing that $C$ paraputrificum was active in the dehydrogenation of steroids but that this metabolic activity was not restricted to a particularp species, $C$ indolis and other species also being active However. fewer active strains of all groups werd represented among those strains isolated from low incidence areas. Consideration of these studies underlinco the importance of examination of the metabolic activitiesw of bacteria in epidemiological studies. These data of carriage rate of clostridia with the potential to dehyde rogenate the steroid nucleus have now been corrected $t(\mathbb{D}$ give the carriage rate of clostridia that actually possessec ${ }^{5}$ this capability in vitro (Figure). Crowther et $a l^{10}$ did not show a relation between NDC carriage and large bowe cancer incidence in three socioeconomic groups in Hons Kong, all three groups having low carriage rates. A recen $\mathbb{8}$ study found carriage rates of NDC of $40 \%$ in Danes, whe 


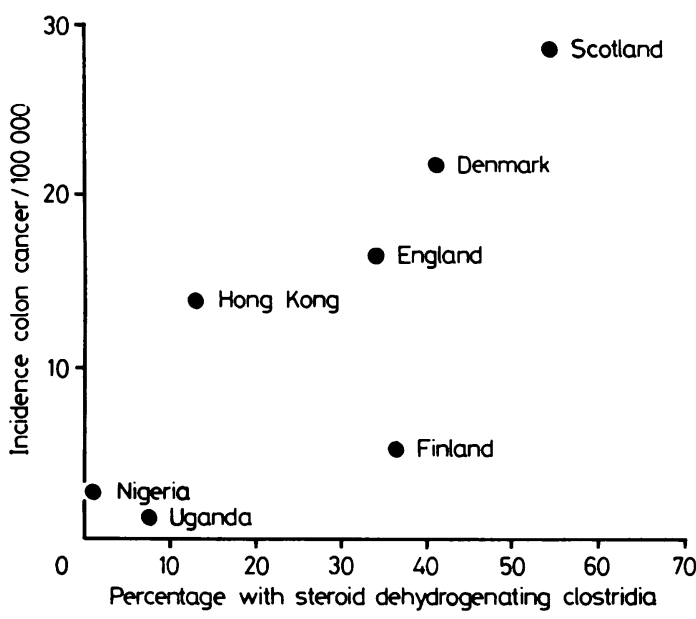

Relation between carriage of nuclear dehydrogenating clostridia and colon cancer incidence. Data of Goddard et al, ${ }^{6}$ Crowther et $\mathrm{al}^{\prime \prime}$ and IARC. ${ }^{16}$

have a high incidence of colorectal cancer, and 38\% in Finns, who have a low incidence of the disease ${ }^{16}$ (Figure). The carriage rate of NDC and the incidence of large bowel cancer in the Danes were similar to those of the English population studied both in this study and the case control study by Hill et al. ${ }^{7}$ The carriage rate in Finns is clearly anomalous in this respect and indicates that the relation bet ween carriage of NDC and colorectal carcinogenesis is not a simple one (Figure).

The data reported here show that Nigerians, who have a low incidence of large bowel cancer 121217 and of potentially precancerous lesions ${ }^{10}$ also have a very low carriage rate of NDC; these results are in striking agreement with the evidence of low NDC carriage for Uganda and Hong Kong. ${ }^{69}$

The results of this study add support to the suggestion that the carriage rate of NDC in a population is related to the risk of colorectal carcinogenesis in that population. It is hoped that prospective studies currently in progress will help clarify this possible aetiological relation.

This study was partly financed by a grant from the Medical Research Council.

\section{References}

'Doll R. The geographical distribution of cancer. $\mathrm{Br} J$ Cancer 1969:23:1-8.

${ }^{2}$ Correa P. Haenszel W. The epidemiology of large-bowel cancer. Adv Cancer Res 1978:26:1-141.

${ }^{3}$ Hill MJ. Drasar BS. Bacteria and aetiology of cancer of the large intestine. In: Balows A, Dehaan RM. Dowell LV. Guze LV. eds Anaerobic bacteria: role in disease Illinois: Thomas Springfield. 1974:119-34.

${ }^{4}$ Borriello SP. Carcinoma of the colon and gut bacteria. In: Goodwin CS. ed. Gut microbes in health and disease. Oxford: Blackwell Scientific. (in press).

'Hill MJ. The aetiology of colorectal cancer. In: Wright R. ed. Recent advances in gastrointestinal pathology London: Saunders. 1980:297-310.

${ }^{6}$ Goddard P. Fernandez F, West B. Hill MJ. Barnes P. The nuclear dehydrogenation of steroids by intestinal bacteria. J Med Microbiol 1975;8:429-35.

${ }^{7}$ Hill MJ, Drasar, BS, Aries VC. Crowther JS. Hawksworth GB. Williams REO. Bacteria and aetiology of cancer of the large bowel. Lancet 1971:1:95-100.

${ }^{8}$ Blackwood A. Murray WR. Mackay C. Calman KC. Faecal bile acids and clostridia in the aetiology of colorectal and breast cancer. $\mathrm{Br} \mathrm{J}$ Cancer. 1978:38:175.

${ }^{9}$ Drasar BS, Goddard P. Heaton S. Peach S. West B. Clostridia isolated from faeces. J Med Microbiol 1976:9:63-71.

${ }^{10}$ Crowther JS. Drasar BS. Hill MJ. et al. Faecal steroids and bacteria and large bowel cancer in Hong Kong by socioeconomic groups. $\mathrm{Br} \mathrm{J}$ Cancer 1976:34:191-8.

11 Williams AO. Prince DL. Intestinal polyps in the Nigerian African. $J$ Clin Pathol 1975;28:367-71.

12 Adekunle OO. Abioye AA. Adenocarcinoma of the large bowel in Nigerians: a clinicopathological study. Dis Colon Rectum 1980;23:559-63.

${ }^{13}$ Crowther JS. Transport and storage of faeces for bacteriological examination. J Appl Bacteriol 1971:34:477-83.

${ }^{14}$ Borriello SP. Hudson MJ. Hill MJ. Investigation of the gastrointestinal bacterial flora. Clin Gastroenterol. 1978:7:329-49.

${ }^{15}$ Borriello SP. Cohen BA. A rapid micromethod for the detection of indole production from tryptophan. Microbios Lett 1978:5:7-11.

${ }^{16}$ International Agency for Research on Cancer Intestinal Microecology Group. Dietary fibre, transit-time, faecal bacteria, steroids and colon cancer in two Scandinavian populations. Lancet 1977;1:207-11.

${ }^{17}$ Doll R. Muir CS. Waterhouse J. Cancer in five continents Berlin: Springer-Verlag, 1970:II.

Requests for reprints to: Dr SP Borriello. Division of Communicable Diseases, Watford Road, Harrow. Middlesex HAl 3UJ. England. 